\title{
That latent sense of otherness: old and new anti-semitisms in postwar Italy
}

\author{
Giacomo Lichtner* \\ School of History, Philosophy, Political Science and International Relations, Victoria University of \\ Wellington, $N Z$
}

(Received 31 July 2018; final version accepted 20 August 2018)

\begin{abstract}
This article traces the evolution of anti-semitism in post-war Italy, from the early responses to the Holocaust to the increasingly concerning signs of contemporary antiJewish prejudice. Tracing the discourses of religious and secular attitudes towards Jews, the piece shows how resilient certain stereotypes are, and how assumptions about citizenship continue to undermine the respect of difference in Italy. With a reflection that is meant to be personal and scholarly at the same time, this contribution has the aim of facilitating a broader reflection, that spans instances of anti-semitism among the antiracist Left, the correlation between unresolved anti-Jewish prejudice and widespread racist, anti-immigrant discourses, the challenges of a politicised memorialisation of the Holocaust, and also the role Jewish communities may play in this unsettling context.
\end{abstract}

Keywords: Italy since 1945; anti-semitism; Holocaust memory; Catholic-Jewish relations; anti-Zionism; racism.

\section{Introduction}

My mother was born in Rome on 21 July 1944, of a Catholic mother and a Jewish father, Rodolfo Passigli. Rodolfo was the youngest son of a bourgeois Florentine family: his father had managed a toy factory and his mother ran a well-known textile shop on the corner of Piazza delle Signorie. Rodolfo had married a Catholic woman and been employed in the Ferrovie dello Stato, until the Racial Laws of 1938 cost him his job, alongside other Jewish civil servants and professionals. While not unusual in the 1930s, marriage to a Catholic woman cost him the acceptance of his own community but did not help him gain it elsewhere, or secure exemption from the old and new prejudices of Italian society.

Rodolfo was not around for the birth of his third daughter: arrested in his native Florence in the spring of 1944, he was deported to Fossoli and then Auschwitz, where he was gassed in April. At the time of his arrest, the Italian police told his mother Stella that her two sons would suffice, and that they were prepared to pretend not to have seen her. Stella left police headquarters, visited some friends and returned later that day, to join Enzo and Rodolfo. Rodolfo's wife, Olga Rossi, survived the latter stages of the war in constant fear for her two young daughters, who did not appear in any community register but were nevertheless half Jewish, and for the child in her womb, threatened by the hardships of war as much as by the German occupation. By the time Olga's pregnancy went to term Rome had been liberated, her husband and his family murdered,

\footnotetext{
*Emails: giacomo.lichtner@vuw.ac.nz
} 
and their fortune gone. Her new baby's link with Judaism was another casualty of war: she was christened Maria Cristina and denied her paternity through a bogus birth certificate, just in case.

Maria Cristina Passigli died in July 2017, days before her seventy-third birthday, and although her life was not paradigmatic of the postwar Jewish experience in Italy, it will serve here as a road map, to follow the evolution of anti-semitism in Italy.

\section{'The devil walks behind you'}

As a child, Maria Cristina (hereafter Cristina, as everyone knew her) was sent to school with nuns on Via Paolo III, a stone's throw from the Vatican. She was after all a baptised Catholic, like her sisters, and unlike her sisters she bore her mother's surname, Rossi, which should not have aroused much suspicion. Nevertheless, her teachers knew better, and she never forgot being reminded of her Judaism at every opportunity, and of the seemingly indelible guilt for the crucifixion she somehow shared in. 'The devil walks behind you' was the terrorising reminder the sisters felt compelled to offer the orphan in their charge.

We know enough about Catholic institutions in the twentieth century to imagine that other children - Jewish and Gentile - might have suffered similar threats, or much worse. We will never know for sure, but it is at least plausible that a disciplinarian intent, rather than rabid anti-semitism, motivated her teachers. Nevertheless, here is a useful starting point: it is 1950, Italy is rebuilding; the racial laws are an increasingly distant memory to be attributed - if they were ever discussed to Nazi Germany or a few fascist cowards; the German concentration camps are a centrepiece of antifascist memory; and the amnesty of 1949 has archived any postwar purge. No Nuremberg needed. Yet a six-year-old child walks with the devil close behind because her murdered father was Jewish, and because local nuns knew more about her parenthood than her, or even the state. It is a reminder of the complexity of anti-semitism in Italy, of its deep roots and shallow, violent offshoots.

Italian Jews returning home from their hiding places or from the Camps in 1945 did not find the people 'still strong, still capable of hatred, still prisoner of pride and guilt' that Primo Levi had seen in the eyes of defeated Bavarians in his brief Munich stop on the journey back to Turin (Levi 2003, 323) however, indifference, silent prejudice, hypocrisy, patronising compassion were more likely responses. Guri Schwarz expressed this state of affairs with uncompromising eloquence when he wrote: 'Immediately after the fall of the fascist dictatorship we witness the consolidation of an interpretation of the anti-Jewish policy which erased even the slightest reference to a specific Italian responsibility' (Schwarz, 2012) Robert Gordon traced the public contours of this whitewash among anti-Fascist commemorations, private and group memory, selective narratives and deliberate appropriation (Gordon, 2012). Gordon and Schwarz both isolate in Eucardio Momigliano's Tragic and Grotesque History of Italian Racism the historiographical origins of a brazen denial of autochthonous anti-semitism that would quickly become orthodoxy.

There are many utilitarian and psychoanalytical arguments that explain the search for a swift closure: Levi understood how the pressures of physical and psychological reconstruction explained the lack of public interest in the Camps, and even in Hasidic Jewish tradition there is a place for 'not remembering'. ' Yet in other ways postwar Italy revelled in memory, especially in that of the Resistance struggle. To some extent, Jewish victims of the Holocaust benefited from being automatically welcomed in the reassuring folds of anti-Fascist martyrdom, yet the price of acceptance into nationalist and communist memory frameworks was often the denial of their individual identity, or of the circumstances of their deportation. There was more to Italian efforts to move on with little or no acknowledgement of its racial persecutions than a highly successful 
self-exoneration strategy, emboldened by an international decision to frame Nazi crimes as crimes against humanity. While we would do well to mistrust rigid causal explanations, it is hard not to read in this early failure to elaborate the legacies of Italian racism (against Jews but also, perhaps especially, Africans) the single most important cause of its later resurgence.

While the demise of Fascism had spelt the defeat of state-sanctioned biological racism in Europe, older prejudices remained, of both a religious and xenophobic nature. Italian reactionaries, populists and variously-recycled fascists were not as explicitly anti-semitic as the Poujadists in France, who were drawn into public displays of old prejudice by Pierre Mendes-France and decolonisation, yet anti-Jewish sentiment persisted in Italy as in the rest of Europe. The reflection by George Orwell - himself infamously prone to anti-semitic stereotypes - that British resentment had increased with the war, but that few would subscribe to the word anti-semitic, may well have applied to Italy, too (Orwell 1945). As Elena Mazzini has written, in 1946 Italy it was acceptable to publish Giovanni Papini's Lettere agli uomini di Papa Celestino VI, which explicitly blamed the Jews' rejection of Christ for two millennia of subsequent discrimination and persecution, and it was no scandal that the well-respected Enciclopedia Cattolica would distinguish between legitimate and illegitimate anti-semitisms (Mazzini 2013, 362; 382). Nor was this exclusively the remit of intransigent Catholicism or nostalgic fascists. As Gordon has shown, even Liberal icons like Benedetto Croce, far from atoning for his cowardly abstention in the Racial Laws vote of 1938, continued to warn Jews not to draw attention to themselves, or display their distinctiveness in an ostentatious manner, by insisting on a 'barbaric and primitive religious culture' (Gordon 2012, 45). It is hardly surprising that Jews went about the business of 'not remembering' and 'not forgetting' in a private and discrete manner, or that those who tried to commit their memoirs to print found an unwelcome response, experienced as a discourtesy by Italians. Anti-communism was much more fertile territory in the late 1940s and 1950s, but xenophobic rhetoric and the persistence of a perception of Jews as not fully Italian were not defeated - they were perhaps not even tackled - allowing an unthinking, subcutaneous prejudice to persist.

Still, Italian tolerance was not just a convenient myth, and lingering anti-Jewish sentiment seldom crawled its way to the surface in Italy. One such isolated act took place in May 1958, when the memorial plaque to the deportees outside Rome's central synagogue was vandalised. An Istituto Luce newsreel dedicated its newsflash rubric, Questa Volta in Primo Piano, to the event (Istituto Luce, 1958). It consists of 52 seconds that are worth dwelling on. The scene opens with children depositing flowers at the foot of the plaque: 'The people of Rome know how to respond appropriately to this shameful act', as though the vandals had not likely belonged to the same Roman population. Pursuing the anachronisms of selective memory, the footage cut to three German soldiers patrolling the city, and then to the Fosse Ardeatine. The voice-over, meanwhile, asked: 'Maybe the vandals who carried out this mission dream of resuscitating some of these Nazi laws', before launching in to an astonishing list of German legislation, starting at the 1935 Nuremberg Laws and neatly sidestepping Italy's own 1938 racial laws.

The year 1958 was also when Einaudi published Levi's Se questo e' un uomo, a decade late, and the year Angelo Roncalli was ordained as John Paul XXIII, a turning point in Catholic-Jewish relations. And, if we zoom in for a moment, 1958 was also the year that my mother crossed the Tiber to attend the prestigious Liceo Classico 'Virgilio'. There, on the first day of high school, she found herself absent from the roll: her father's name had been reinstated without notice. One day she had crossed Ponte Mazzini as Cristina Rossi and returned home as Cristina Passigli. The change of name had an immediate casualty: a friend told her he was no longer allowed to see her because she was Jewish. Letting her attend high school was a statement of social intent and a financial effort for her cash-strapped single mother of three, but the sudden name change bore a 
cost beyond the loss of a friend. As Cristina left the nuns for the classrooms of Rome's bourgeoisie, she traded a stalking devil feeding on the guilt of the half-Jewish Catholic orphan, for a new, secular trauma that would haunt her for years to come.

\section{Maccabees and Morris Minors}

In December 1961, as the world awaited the sentencing of Adolf Eichmann, the Communist Party's L'Unità published a short, insignificant but remarkable article reflecting on the Jewish holiday of Hanukka and linking the Maccabees, as partisans ante litteram, with the agency of the Israeli state in seeking out Nazi criminals, capturing them and putting them on trial. The publication of Levi's memoir and the Eichmann trial marked a decade in which the Nazi crimes against humanity became recognised as a specific extermination of Europe's Jews, allowing Jewish memory to emerge as legitimate, and be accepted as both specific and of universal interest. Accompanied by the reconsideration of Italy's Fascist past that the generational transition of the 1960s threatened to bring about, this was a fertile moment for considering the impact of racism and anti-semitism in the country. This undercurrent of reconciliation and recognition was picked up in popular culture, if not always in public opinion. When Roberto Rossellini, in a crucial scene of $I l$ Generale della Rovere (Rossellini, 1959) showed condemned Jews at prayer, no reviewer noticed the generalised absence from popular culture that sudden appearance illuminated. In the same scene, Rossellini has a petty bourgeois Milanese man caught in the same German raid complain of his innocence:

Milanese man: 'I haven't done anything.'

Jewish man: 'Why? What are we supposed to have done?'

M. M.: 'You are Jews!'

Moments later, an undercover Resistance leader held in the same cell chastises the Milanese man: 'you said that you didn't do anything; exactly, why did you do nothing?'

Reviewers who hailed Rossellini's return to neorealist themes saw in this less-than-subtle conversation a call to commitment, to impegno, rather than a reflection on the unthinking antisemitic bias that had made Italians broadly supportive or indifferent of the racial laws. Yet it represented a turning point nonetheless, as did Carlo Lizzani's L'Oro di Roma (Lizzani, 1961) which may have still condemned religion as passive and politically suspect, but was nevertheless tender and compassionate towards Roman Jews and their history of tolerant discrimination. Lizzani's film was also significant insofar as it approached the thorny subject of Catholic-Jewish relationships. One of the two protagonists, Giulia, marries a bourgeois Catholic man and converts to Catholicism, yet cannot abandon her community when she witnesses their deportation. Lizzani also showed the Vatican guaranteeing the Jewish community's efforts to collect $50 \mathrm{~kg}$ of gold to satisfy the German blackmail, days before the deportation. The loan was ultimately redundant but Lizzani shows Pius XII as empathetic but cautious; in Lizzani's analysis, class and political commitment are the real issues, and a sense of shared Romanness seems to trump religious differences.

The 1960s were a crucial decade for Catholic-Jewish relationships, as John Paul XXIII and his successor, Paul VI, continued the work of reforming the Catholic Church, its doctrine and its attitude to non-Catholics. Vatican II could not solve generations of ignorance, prejudice, stereotype and Sunday sermons, but it did at least withdraw the accusation of deicide that had hung over Jews for centuries. The encyclical accompanying the Council's findings, Nostra Aetate, remains a 
direct and powerful call to tolerance and openness, but also an example of the ambivalence of Vatican diplomacy. In a crucial passage, it reads:

True, the Jewish authorities and those who followed their lead pressed for the death of Christ; still, what happened in His passion cannot be charged against all the Jews, without distinction, then alive, nor against the Jews of today. Although the Church is the new people of God, the Jews should not be presented as rejected or accursed by God, as if this followed from the Holy Scriptures. All should see to it, then, that in catechetical work or in the preaching of the word of God they do not teach anything that does not conform to the truth of the Gospel and the spirit of Christ.

Furthermore, in her rejection of every persecution against any man, the Church, mindful of the patrimony she shares with the Jews and moved not by political reasons but by the Gospel's spiritual love, decries hatred, persecutions, displays of anti-semitism, directed against Jews at any time and by anyone.

Besides, as the Church has always held and holds now, Christ underwent His passion and death freely, because of the sins of men and out of infinite love, in order that all may reach salvation. It is, therefore, the burden of the Church's preaching to proclaim the cross of Christ as the sign of God's all-embracing love and as the fountain from which every grace flows. (Paul VI 1965)

On the one hand, Paul VI issued a direct and unequivocal order to Catholic priests and prelates to cease any direct reference to Jews as accursed killers of God, and explicitly decried anti-semitic acts: it is impossible not to see a remarkable break in these passages. One the other hand, the final paragraph suggested that Jews were absolved of responsibility for the crucifixion because Jesus's martyrdom was voluntary. This allowed the traditional interpretation to endure, and when the Pope wrote that 'by His cross Christ, Our Peace, reconciled Jews and Gentiles, making both one in Himself' (1965), he effectively denied the very distinctiveness based on mutual respect the Encyclical purported to promote. As former Catholic priest James Carroll would write in regard to the controversy of the Carmelite crosses at Auschwitz:

Once, for Christians to speak among ourselves about the murder of six million as a kind of crucifixion would have seemed an epiphany of compassion, paying the Jews the highest tribute, as if the remnant of Israel had at last become, in this way, the Body of Christ. Yet such spiritualizing can appear to do what should have been impossible, which is to make the evil worse: the elimination of Jewishness from the place where Jews were eliminated. (Carroll 2002, 7)

At the same time as the Vatican was wrestling with its difficult legacies, the state's secular authorities trod a similar kind of path, lined with progress and lingering ambiguities. On 16 October 1968, speaking in Rome's former ghetto on the twenty-fifth anniversary of the Nazi raid on Rome's Jews, President Giuseppe Saragat said:

Any civilised person, any Italian citizen, cannot but feel a sense of guilt towards the Israelites who for centuries have been victims of fanaticism, and who during our own times were exterminated by Nazi barbarism. Alongside such ferocity we cannot forget the acts of mercy which the Church, civilian authorities and the Italian people were able to offer to persecuted Jews at the time of their worst affliction.

For as long as violence overwhelms reason, it will be necessary for the spirit of the Resistance, which renews the spirit of the Risorgimento, to remain vigilant. You Jews who are the part of the Italian people most affected by the foreign invasion, will no doubt understand what I have just said. The spirit of the Resistance means the refusal of injustice, of the violation of human rights; it means, most of all, awareness.

Compared to other European countries occupied by the Nazis, Italian Jews lived - until September 1943 - in circumstances that cannot be considered harsh. The racial laws - issued by Mussolini's government - were applied in a spirit of tolerance and moderation and the Jews lived in an atmosphere of relative safety. 
However, this period of calm ended with the German occupation, and Roman Jews became its first victims. (Mazzini 2013)

In Saragat's speech, a rare and quite radical hint at collective responsibility is immediately neutralised by a litany of exceptions. On the one hand, Saragat convincingly spelt out concrete commitments emanating from the ever-present 'spirit of the Resistance'; on the other, he linked it to the Risorgimento without any awareness of the continuities between Liberal and Fascist Italy, and especially of the responsibility of nationalism in the development of Italian racist policies. Inevitably, the convenient counterpoint of German barbarism serves further to undermine any call for Italian introspection, in spite of the fact that the twenty-fifth anniversary of the German deportation was also the thirtieth of the passing of the Racial Laws. Most interestingly perhaps, Saragat seemed to offer the Jews a trade that foreshadowed the main problem with the contemporary evolution of conceptions of the Holocaust as a Judeocide: primacy in victimhood and acceptance in the national fold ('the part of the Italian people most affected'; 'first victims') in return for the survival of uplifting and absolutory national narratives.

Modern European anti-semitism, in all its incarnations, is at its core about citizenship: the tension between emancipation and acceptance of diversity, on the one hand, and the desire for homogeneity of the nation state. In 1967, the Six Day War presented a new challenge in this respect, as Jews found themselves torn between the politics of their homeland and the survival of the state of Israel. Although the Suez crisis in 1956 had already strained the Italian Left's relationship with Israel, it was not until 1967 that the romantic perception of Israel as an underdog born of socialism and genocide, a land of kibbutzim and pioneers, made way for a new critique, based on accusations of imperialism, Americanism and racism. The same anachronistic language of Resistance applied to the Maccabees by L'Unità in December 1961 had been transferred, by the decade's end, to the Palestinians. This was the beginning of a historic shift in the Left's approach towards Jews: the end of a historic alliance against Catholic conservatism, reactionary oppression and fascism. This is not the place to revisit the arguments of Middle Eastern politics; what concerns more closely the subject of this volume is that the ambiguity of the Left's distinction between anti-Zionism and anti-semitism rejuvenated old assumptions of disloyalty, or double loyalty, and set back postwar efforts to de-nationalise discourses on Italian Jews. By 1982, when Israel invaded Lebanon and PLO terrorists followed up a spate of missions in Europe with an attack on the synagogue in Rome, killing two-year-old Stefano Taché, public response was muted. The contemplation, even left implicit, of an argument that justified the murder of European Jews with the conflict in Palestine crossed new territory: anti-Israeli rhetoric had ushered in 'a new system of signs which had at its heart the image of the Jew', as Schwarz devastatingly notes. (2012, 189).

Like many of her generation, Cristina negotiated Catholic education in the 1950s and a bourgeois high school in the 1960s by graduating into the Communist Party. In 1966 she had changed surname for the third time, marrying another Rodolfo, who was also son of a Catholic mother and Jewish father, and who also had been educated by Jesuits to become a (rather erudite and disciplined) young Communist. The cooling of the Left's relationship with Judaism did not stop their militancy throughout the 1970s, but also did not define their view of Israel, where the only survivor of Rodolfo's Hungarian family had found refuge from the Holocaust. In 1977 their wood-panelled Morris Minor was burnt by the neo-fascist Nuclei Armati Rivoluzionari: a reminder - if any were needed - that even as the Left's attitude to Jews was becoming ambiguous there was nothing ambiguous about the ongoing threat of right-wing violence. 


\section{Immigration and the intersectionality of intolerance}

In 1997, Ettore Scola directed a short film, 1943-1997, in which he returned to themes dear to him: Fascist Italy and the Occupation (Scola, 1997). The 8-minute film, which contains no dialogue, opens in the alleyways of Rome's ghetto on the morning of 16 October 1943: a grey morning, according to survivors, with the first autumn chill. As the German soldiers start arresting Jews, a small boy hides in a fold-down mattress and, when the shouting dies down, escapes into the street. Finding refuge in a cinema, the boy grows old watching a montage of postwar Italian cinema: the canon of neorealism and the commedia all'Italiana, from Rossellini to Monicelli, Cavani to Moretti, all the way to Francesco Rosi's La Tregua (The Truce, 1997) and the scene of Levi's liberation. As the lights come on to reveal the now elderly Jew, an African boy tears into the theatre, running for his life much like the old man four decades earlier. He sits behind the old Jew, and they share a silent and slowly complicit glance before the lights dim anew for the show to start again. This little masterpiece was almost certainly the idea for Scola's Concorrenza Sleale (Unfair Competition, 2001) and quietly achieves the connection of old and new Italian intolerance that his feature film would fail to embody. (Lichtner, 2012) While 1943-1997 cannot help but contain humour, compassion and hope, it is also an indictment: there is belief in humanity's endurance but also an inescapable feeling that tolerance is an eternal struggle. The cinema may be cathartic, and magical, but it is also a truce, an escape from the violence outside, and there is something terrifying about the resignation that we can no longer leave its lonely embrace.

Immigration made an immediate impact on the resurfacing of Italian racism, which has grown exponentially since the turn of the twenty-first century, becoming bolder, and both more aggressive and more mainstream. Jews certainly did not face the systematic, brazen discrimination that Roma and Sinti, Africans and other minorities routinely endure, yet anti-semitism has risen handin-hand with the creeping of racial discourses into the arena of the politically and socially acceptable. The demise of the post-Fascist convention that had made discrimination shameful should be a concern of all minorities in Italy, even if it has not affected them all evenly, or constantly.

The Centro di Documentazione Ebraica Contemporanea (CDEC) in Milan has been tracing the rise of anti-semitism for a decade now, and the picture its regular reports paint is grave. Old and new strands of anti-semitism clearly coexist, finding fertile territory in the darker recesses of the internet, but rapidly advancing from niche neo-Nazi chatrooms to Holocaust denial websites, and on to the comments sections of mainstream sites, all the while migrating into the mainstream media, the political debate, stadia, classrooms. The evidence of recent years - from the Jewish Brigade being evicted from 25 April marches to Lazio fans' violation of Anne Frank's image - is well known and, once it is collated, disturbing. I will not make a compendium here but it is worth picking out some of the less scandalous instances, where one by one the ancient, unresolved stereotypes can be found.

On the one hand, Catholic anti-semitism continues to exist, in spite of four decades of Vatican II. In March 2009, a high-school teacher criticised the Catholic hierarchy for removing the word perfidi from the doctrine. When a reader wrote in protest to the conservative Roman newspaper $I l$ Tempo, the editorial responded that it had been appropriate to remove the offensive word, but that 'one should not go overboard in defending [the Jews], lest one believe that Jesus died of natural causes' (CDEC 2010). In the same year former Director General of Rai Ettore Bernabei defended the Church from the paedophilia scandal, telling Corriere della Sera that 'There is a design to paralyse economically the Catholic Church, which does not obey the lobbies of global finance' (CDEC 2010). And in 2010, also defending the Church in Pontifex, Giacomo Babini, former 
Bishop of Grosseto blamed the paedophilia scandal on 'the enemies of Catholicism: freemasons and Jews', but especially Zionists, because 'after all, historically speaking, the Jews ( $i$ Giudei) are deicides' (CDEC 2010, 11).

However, these rare instances of nostalgic religious anti-semitism appear minor when compared to a secular anti-Jewish sentiment emerging from anti-Zionist and anti-capitalist critiques. For instance, in 2008, the right-wing blog Il Cannocchiale published a list of academics with Jewish surnames, arguing that these 'demonstrated how a public state institution ... has been exploited by an ethnic minority that is ideologically and culturally aligned with a foreign political entity such as Israel' (CDEC 2010, 6). In the same year, the left-wing trade union Flaica-Uniti $\mathrm{Cub}$, which represents self-employed merchants, proposed a boycott of Jewish shopkeepers, while the neo-fascist Militia took matters into its own hand, sealing shut the doors of 22 shops owned by Jews (CDEC 2010, 8) In these anti-semitic attacks there is evidence of a synergy which is partly new and partly ancient. It is new because it is a synergy built on a shared anti-systemic fervour, centred on angst around the perceived demise of twentieth-century certainties around class, work, and ideology, and the Jews become perhaps for the first time the embodiment of 'the system', after centuries as the minority that even success could not quite render acceptable. Yet these attacks are also old, ancient even, because they target anxieties around the dissimulation of identity (hence the need to identify surnames) and because in targeting shopkeepers they clearly evoked well-worn stereotypes.

The year 2008 was of course a significant date, and there are many examples of Bernie Madoff being isolated as the epitome of a Jewish lobby controlling global finance. Once again, the arguments, the techniques employed to make them and their resonance among the population provide clear echoes of distant and not-so-distant anti-semitisms, including the infamous Protocols of the Elders of Zion, a text that not by accident begins to circulate yet again in these years. The anti-semitic response to the Great Financial Crisis suggests, on the one hand, a lingering antiJewish sentiment, built on old stereotypes unaddressed by Italian society since the war, and on the other hand, a sort of fickle anti-semitism - both deep-seated and shallow, if that is possible - that responds and adapts to short-term developments. So, for instance, a 2008 survey of perceptions of the Jews amongst Italians found that the percentage of people who believed Italian Jews to be more loyal to Israel than Italy had fallen by eight per cent in three years (from 57 to 49 per cent) while those who believed in Jewish control of world finance had grown by the same amount (42 to 32 per cent) (CDEC 2010).

We cannot underestimate the fact that the last ten years have seen little worsening of Italian perceptions of Jews and that equivalent European surveys suggest that anti-semitism remains much stronger elsewhere (CDEC 2017). However, perhaps the most interesting aspect of the regular CDEC-IPSO surveys of these years is the grey area of Italians who declare they neutral (CDEC 2010 and 2017). Are they afraid to answer, uncertain, tacitly in agreement with the stereotypes in question, or just indifferent? How do we explain 53 per cent of respondents neither agreeing nor disagreeing with the statement 'the Jews always manage to obtain a disproportionate political power', or 55.6 per cent who felt the same way about alleged Jewish control of the media? In the same vein, the 15.1 per cent of Italians who believe, according to the survey, that 'Jews have always lived on other people's backs' looks less encouraging when matched with 55.6 per cent in the grey area. It is difficult to interpret these data. CDEC make a convincing point when they note that 84 per cent of the population does not know personally a single Jew, but the historical landmark this special issue marks reminds us that ignorance and a small, eminently well-integrated minority are no guarantee of safety (CDEC 2010). 
The combination of this majority (whose uncertainty remains hard to define), a hard core of neo-fascist anti-semitism, and the new anti-semitism of some on the Left is a concern. The latter, however, is the newest and most interesting phenomenon. There is an orientalist self-righteousness in some left-wing discourses of Israeli imperialism and Palestinian victimhood that wilfully ignores the complexities of the Middle East and exposes Europe's colonial past. These discourses are rife with ethnic essentialisation and the old Western vice of moulding other cultures and parts of the world in its own image. Generalisations about the Israeli-Palestinian conflict are often ignorant, facile and unhelpful, but not in themselves anti-semitic. Anti-Jewish prejudice emerges, however, in two specific tendencies: first, in the inability to distinguish between government policy and a diverse Israeli population, including a heterogeneous ultra-Orthodox minority; and second, in the assumption that it is legitimate to hold Jewish communities outside of Israel responsible for Israeli policy. It is hard not to see in both behaviours a discrimination towards Jews. Concerning the former tendency, there seem to be few if any examples of such superimposition happening in other geopolitical context. Meanwhile, the tendency to presume an association between a country and its ethnic diasporas, or between a religious faction and all devotees of that religion, has some clearer international referents, but these are invariably the realm of the racist Right, not of the progressive Left. As we have seen, evidence about the reasons for such special treatment is easily found in the old stereotypes of Jewish greed, arrogance and corporatism that are routinely peddled in both left-wing and right-wing circles. In these respects, the new form of antisemitism that Schwarz identifies is adjacent to older forms of prejudice, and feeds on them.

The shifting but ongoing subtexts of religious and political anti-semitism in Italy underpin an antagonism that has significantly evolved but has not been truly resolved. It is of particular interest that the recent re-emergence of anti-semitic discourses has coincided with the definitive institutionalisation of Holocaust memory, at least since the United Nations' decision to mark the Holocaust with a dedicated memorial day. Is there a relationship between these events? And if so, is it purely an anti-semitic reaction to the public acknowledgment of Jewish memory, akin to the post-Enlightenment reaction to emancipation, or is there something more?

Since the sixtieth anniversary of the Racial Laws, commemorating the Holocaust in Italy has too often lost any historical specificity and become a perfunctory statement of intent. But the problem is not only the meaningless relativism of the secular commandment 'never again'. In Italy, though not only there, commemorating the Holocaust has become a form of virtue-signalling, initially for the post-fascist but increasingly also for the anti-Zionist Left. Declaring that the Holocaust is unparalleled evil allows politicians, at need, either to claim instant democratic and anti-fascist credentials or to claim immunity from the ambiguous line distinguishing anti-Zionist and anti-semitic rhetoric. Gianfranco Fini's trip to Israel in November 2003, where he declared that fascism was 'absolute evil', may have been the first instance, but it is certainly not the only one. Matteo Salvini has repeatedly courted Israel for the same reason, even as he shuts Italian ports to desperate migrants, plots racist laws against Roma communities, incites racist rhetoric and exploits xenophobia against other minorities. Between the old post-fascist Right he helped recycle and the new neo-fascist Right he helped create, it is worth placing Silvio Berlusconi. His statement, on 27 January 2013, remains paradigmatic of a trade-off that Italy's Jewish communities should not be seduced by. When the former Prime Minister declared that 'the Racial Laws were the worst mistake of a leader, Benito Mussolini, who had also done good things', he held up the Holocaust with one hand and waved in racists and fascists with the other, both historically - by his silence on Italian colonial crimes in Africa - and politically, by winking at neo-fascist voters (Berlusconi 2013). 
This kind of decontextualised and institutionalised memorialisation seeks to impose a kind of artificial closure, which actually silences the experiences of the victims and may even have done a disservice to the long-term tackling of racism in Italy. On the one hand, Holocaust denial was added to the armoury of the self-satisfied ranks of anti-PC discourse peddlers; on the other hand, that memorialisation effort seemed to create a primacy of anti-semitism over anti-immigrant racism, allowing populist and right-wing racism to cleanse themselves in a perfunctory rebuke of the 1938 Racial Laws. As much as it is important to remember that Italian Jews are individuals, holding myriad different views and, like other Italians, susceptible to feeling threatened by the perception of rampant immigration, Jewish communities have a specific responsibility here: they must hold firm in reminding wider society of both the historical specificity of the Holocaust and of its relevance. They have a history of doing so forcefully and urgently, most recently in protesting strongly against the proposed coerced registration of Roma peoples; their strength is likely to be tested by growing prejudices against Muslim migrants, and the understandable fears of radicalised anti-semitism, so deadly in France and elsewhere. As I hope this article has demonstrated, it would be foolish to believe that anti-semitism in Italy is irrelevant or past, and that anti-immigrant prejudice does not share its racist historical roots.

\section{'Here are the keys. Do as you see fit.' ('Ecco le chiavi. Fate voi.')}

In 1990, I saw my mother lose consciousness for the first time. Seemingly in a dream, she talked aloud of a concentration camp, as if she were in it. She alternated the details of her nightmare and communicating with those around her, but she was unable to wake up or be roused, until the nightmare had concluded with a traumatic reliving of extermination by gas. It would be many years before I would learn that this was not an uncommon symptom for second-generation survivors, as Israeli doctors started to discover in the 1970s. I also learnt later that my mother had had similar episodes before, but I only witnessed it one more time, five years later: Cristina was about to convert to Judaism and her family panicked, questioning her paternity once again. The episode passed and Cristina went on to reclaim as her own all the names she had been given by others, and adopt a new one to assign to the next chapter.

My mother spent the last twenty years of her life as a Jew and found solace in the religion of her forefathers. When she died, on a hot midsummer shabbat, the staff of the hospital of the small Tuscan town where she died were a little uneasy about Jewish funeral practices. They understood the language of grief, but the technicalities of Jewish ritual, waiting for the end of the sabbath and a rabbi from Rome, removing the crucifix from the room in the morgue, unsettled them: standard practices and regulations were highly likely to be flaunted and they clearly feared saying the wrong thing. 'We shouldn't really' ('Non si dovrebbe'), seemed a familiar prefix to most requests. 'We shouldn't really, but ...' In a gesture of kindness and anarchic resourcefulness that defied my efforts not to buy into the brava gente myth, the crucifix found its way into a drawer and they handed us the keys to the morgue: 'here are the keys. Do as you see fit'. We saw no one else for the best part of two days.

It is a reminder of an ambivalence that is not only Italian, but that is also Italian, between a natural fear of the Other and the ability to see, through the difference, a husband, a child, the heavy work of mourning and allowing others to mourn. It does not escape me that I am closing a piece that has sought to remind the reader of the enduring roots and new shoots of Italian anti-semitism with an uplifting story about Italian humanity. Yet this is not only an accurate ending, nor only a cathartic rhetorical device: it is, appropriately, the recognition of ambiguity as an interpretative key of Italian history, one that historians of Italy may wish to embrace rather than defuse. In the same country that continuously delays the work of accepting diversity, the hospital staff who handed over the keys, and 
those who silently saw us leave them and pick them up again at need, unconsciously replaced the latent sense of otherness that defined postwar Italian Jews with an open, acknowledged difference, and simultaneously accepted that difference, with literally no questions asked.

\section{Notes on contributor}

Giacomo Lichtner is Associate Professor of History and Film at Victoria University of Wellington. A specialist in the role of cinema in constructing memories of the Second World War in Europe, he is the author of Film and the Shoah in France and Italy $(2008,2015)$ and Fascism in Italian Cinema Since 1945: the Politics and Aesthetics of Memory (2013). Lichtner's current projects include the theoretical conceptualisation of film's 'double historicity' and a study of the search for meaning in Holocaust cinema.

\section{Notes}

1. The survivor and Hasidic scholar Israel Spira, Rabbi of Bluzhov, quotes Genesis $(40,23)$ to suggest that there are historical events of such magnitude that they must not be remembered constantly but must also not be forgotten (Eliach 1992:i).

\section{References}

Berlusconi, S. 2013. Corriere della Sera TV 27 January 2013, available at https://video.corriere.it/berlusconimussolini-fece-anche-cose-buone/36e95aa4-6876-11e2-b978-d7c19854ae83 (accessed August 2018).

Carroll, J. 2002. Constantine's Sword: The Church and the Jews - A History. Boston: Mariner Books.

Centro di Documentazione Ebraica Contemporanea (CDEC) 2010. Alcune considerazione sull'antisemitismo 2007-2010. Milan.

CDEC. 2016. Rapporto sull'antisemitismo in Italia nel 2016. Milan.

CDEC. 2017. Stereotipi e pregiudizi degli italiani: dagli immigrati agli ebrei. Milan.

Eliach, Y. 1992. Non ricordare ... Non dimenticare. L'olocausto raccontato con la speranza chassidica nell'umanità. Rome: Città Nuova. (Original edition in English, 1983: Hasidic Tales of the Holocaust. New York: Random House.)

Gordon, R.S.C. 2012. The Holocaust in Italian Culture. Princeton, NJ: Princeton University Press.

Istituto Luce. 1958. 'Roma: ignoti imbrattano la lapide della Sinagoga su cui sono riportati i nomi dei cittadini romani di religione ebraica trucidati dai nazi-fascisti'. Settimana Incom 01659 (29 May).

Lichtner, G. 2012. 'Allegory, applicability or alibi? Historicizing intolerance in Ettore Scola's Concorrenza Sleale'. Journal of Modern Italian Studies 17 (1): 92-105.

Levi, P. 2003. Se questo è un uomo/La tregua. Turin: Einaudi.

Lizzani, C. 1961. L'oro di Roma.

Mazzini, E. 2013. 'Cristiani ed Ebrei dopo la Shoah'. Annali di storia di Firenze, VIII: 361-390.

Orwell, G. (1945) 1968. Antisemitism in Britain. In The Collected Essays, Journalism and Letters of George Orwell Vol. 3, edited by S. Orwell and I.A. Orwell, 332-340. London: Secker and Warburg. Also at www.orwell.ru/library/articles/antisemitism/english/e_antib

Pope Paul, VI. 1965. Declaration on the relation of the Church to non-Christian religions - Nostra aetate. 28 October. http://www.vatican.va/archive/hist_councils/ii_vatican_council/documents/vat-ii_decl_19651028_ nostra-aetate_en.html

Rossellini, R. 1959. Il Generale della Rovere. Zebra Films/SNEG.

Schwarz, G. 2012. After Mussolini: Jewish Life and Jewish Memories in Post-Fascist Italy. Edgware: Vallentine Mitchell.

Scola, E. 1997. 1943-1997. DVD enclosed with Italian Film in the Shadow of Auschwitz by M. Marcus. Toronto: University of Toronto Press. Also at https://www.youtube.com/watch?v=2bxUL8m60jY (accessed August 2018). 


\section{Italian summary}

Questo articolo prende in considerazione l'evoluzione dell'anti-Semitismo nell'Italia post-bellica, a partire dalle prime reazioni all'Olocausto fino ai preoccupanti segnali di riemersione del pregiudizio anti-ebraico nell'Italia contemporanea. Tracciando i contorni dei rapporti tra lo Stato italiano, la Chiesa cattolica e gli ebrei, questo contributo dimostra quanto alcuni stereotipi siano resistenti e adattabili, e quanto un certo concetto di cittadinanza continui ad ostacolare l'accettazione della differenza in Italia. Attraverso una riflessione che si propone di essere al contempo accademica e personale, l'articolo vuole facilitare una discussione più ampia, che consideri da una parte il rapporto tra anti-Semitismo e xenophobia, e dall'altra quello con l'anti-Sionismo, oltre alla politicizzazione della memoria dell'Olocausto e del ruolo, complesso, che le comunità ebraiche possono giocare in questo contesto. 